of man and animals due to infection with ultra. microscopic viruses. His successful work on the cause and prevention of dog distemper, supported by the Field Distemper Fund, is well known. More recently he and his colleagues have demonstrated the presence of a virus in human influenza, and have opened up an experimental line of attack upon this disease by which it is hoped to obtain important results.

\section{Pavlov and the Spirit of Science}

A CORRESPONDENT has sent us the following translation of a note under the title "Bequest of Pavlov to the Academic Youth of his Country", written a few days before his death by Prof. I. P. Pavlov for a student magazine entitled The Generation of the Victors: "What shall I wish for the young students of my country? First of all sequence, consequence and again consequence. In gaining knowledge you must accustom yourself to the strictest sequence. You must be familiar with the very groundwork of science before you try to climb the heights. Never start on the 'next' before you have mastered the 'previous'. Do not try to conceal the shortcomings of your knowledge by guesses and hypo. theses. Accustom yourself to the roughest and simplest scientific tools. Perfect as the wing of a bird may be, it will never enable the bird to fly if unsupported by the air. Facts are the air of science. Without them the man of science can never rise. Without them your theories are vain surmises. But while you are studying, observing, experimenting, do not remain content with the surface of things. Do not become a mere recorder of facts, but try to penetrate to the mystery of their origin. Seek obstinately for the laws that govern them. And then-modesty. Never think you know all. Though others may flatter you, retain the courage to say, 'I am ignorant'. Never be proud. And lastly, science must be your passion. Remember that science claims a man's whole life. Had he two lives they would not suffice. Science demands an undivided allegiance from its followers. In your work and in your research there must always be passion."

\section{Paint Research Station, Teddington}

ON Tuesday, May 19, the Right Hon. James Ramsay MacDonald, M.P., Lord President of the Council, will open the new buildings of the Paint Research Station, Teddington. The Research Association of British Paint, Colour and Varnish Manufacturers, incorporated in 1926, under the presidency of Mr. S. K. Thornley, really began its investigation work in a private laboratory, but soon, in May 1927, occupied a small converted factory at Teddington. Many alterations and additions were necessary, and in 1930 a substantial new block was added to the old building. In the autumn of 1935 a further extension, which Mr. MacDonald will open, was completed; altogether there is now extensive and admirable laboratory accommodation for chemical, physical and technical work, as well as a large library offering excellent reference facilities on all matters bearing upon the related industries. The Association is co-operatively financed with the assistance of the Department of Scientific and Industrial Research, and in common with other and similar research associations has for its aim the application of scientific knowledge and methods to the problems of the industries concerned, which range from paint to printing ink, pigments, varnishes, linoleum and the like. The work up to recent times has been mainly concerned with problems arising out of development and control of manufacture; but a special division has now been formed for the study of paint applica. tion problems, with a corresponding extension of interest to architects, builders and decorators. The original research work carried out at the Paint Research Station is, from time to time, set out in the form of technical papers and bulletins, of which some ninety have been issued to date. In addition, a comprehensive "Abstract Review of Current Litera. ture in the Paint, Varnish and Allied Industries" is published and is available to interested people ; as a reference journal on paint matters this "Abstract Review" is unique.

\section{Technique of Low Temperature Investigation}

THE first lecture of the series arranged in con. nexion with the Very Low Temperatures Exhibition, at the Science Museum, South Kensington, was delivered in the Lecture Theatre of the Museum on Wednesday, April 1, by Prof. M. W. Travers, of the University of Bristol, the title being "The Technique of Low Temperature Investigation". Prof. Travers spoke with the authority of a pioneer, having been associated with Sir William Ramsay in the discovery of neon and other rare gases in experiments carried out at University College, London. These dis. coveries were the outcome of investigations at low temperatures and have resulted in the familiar neon signs and other forms of modern illumination. In tracing the work of various investigators from the time of Michael Faraday, Prof. Travers explained in a popular way with numerous experimental demon. strations the methods by which very low temperatures are attained. Admission to these lectures is by ticket obtainable free of charge from the Museum.

\section{Recent Acquisitions at the Natural History Museum}

Amongst recent acquisitions to the Zoological Department are the skin and skull of a forest hog (Hylochoerus meinertzhageni) from the Aberdare Mountains, Kenya Colony, presented by Mr. W. B. Cotton. Other additions include four wild cats from Argyllshire, presented by Mr. Ernest Baker, a lion skin from British Somaliland, presented by $\mathrm{Mr}$. F. J. E. Manners Smith, the skin of a genet from Mpika, Northern Rhodesia, presented by Capt. C. R. P. Henderson, and the skin and skull of a tahr (Hemitragus hylocrius) from the Nilgiri Hills, pre. sented by Major E. G. Phythian-Adams. Among the purchases are two hundred mammals and birds from Jugoslavia, a country from which the Museum pos. sesses very little material. The Mineral Department 